$\S=-1$

\title{
Mind mapping Approach in Learning History
}

\author{
Akmal Dhiyauddin ${ }^{1}$, Suzana Ahmad ${ }^{1}$, Marina Ismail ${ }^{1}$, Norizan Mat Diah ${ }^{1}$ \\ Faculty Science Computer and Mathematic, Universiti Teknologi MARA Shah Alam 40450 Selangor Malaysia \\ *Corresponding author e-mail: dhiyauddinakmal4@gmail.com
}

\begin{abstract}
Currently, most Malaysian teenagers know very little about Islamic history and its civilizations. Although Islamic history and civilizations are covered briefly in Malaysian school syllabus, appreciation towards the subject is very little. This is because of traditional approach of learning Islamic history does not appealing enough for the students to enjoy and understand the subject matter. The capability of new powerful multimedia tools have enable an improved applications to be developed in order to facilitate a better teaching and learning environment. Nevertheless, anticipation of mental abilities is also significant to engage a better learning process. Due to this matter, a 'Mind Mapping' approach along with the theoretical foundations of teaching and learning tasks are studied and adapted in the Islamic History courseware development. The developed courseware was tested with $(n=10)$ for its effectiveness and user experience. The outcome yielded positive results based on the unique and interesting design.
\end{abstract}

Keywords: Multimedia, Educational Courseware, Mind Mapping, Islamic History

\section{Introduction}

Malaysian Educational institutions are engage in the improvement of the teaching and learning environment from traditional approach to digital and interactive approaches [1]. Students are exposed to computer and internet as they are encouraged to engage with collaborative and active learning [2]. These technology approaches do not mean to take over the educators roles instead they are needed as a complement the existing method [3]. In addition, computer technology increases student's abilities, creativities, self-confidence and experience [1 - 5].

In order to support the country's vision and mission, this research adapted the current multimedia technology to develop an Islamic History educational courseware. Islamic History was chosen by the researcher, because it has less attention from other researcher [6-7] compare to other subjects to be incorporated with current technology. This research development provides a multimedia courseware that will help students to discover Islamic history through interactive manner as a subject revision and a good general knowledge especially to the Muslim students to increase their appreciation to Islamic figures.

\subsection{Mind MAP}

Mind map is one of the learning methods that are proven to be one of the easiest ways to learn. According to [8], mind map is how readers show their ideas using node and diagrams. It is sometimes called concept mapping [9], knowledge mapping [10], and mind mapping [11]. Peoples who use mind map has to organize the mind map and in the same time it helps them learn the information that they want to put in the mind map. According to The University of Adelaide [12], mind mapping is "method for generating ideas by association". Mind map is one of the easiest methods to learn, Mind map make readers use their whole brain and they will see the big picture [13]. According to Jane [13], readers should differentiate between each node with different colour because the colour can separate their different ideas and keep their minds stimulate. Mind map is use to increase the visualisation and learning process more by using illustration approach [14]. A research on a group of students has been conducted by researchers [14], which found that mind map make the students feel keener to learn the topic because of the visual effect used. In addition, students will get new knowledge when they used interactive map courseware. Mind map force students to understand the information in it in the form of symbols, graphs, or short words. Mind map can make the learning period become less boring and give students more time to understand the topic.

\subsection{ISLAMIC HISTORY}

History is a boring subject than student always avoid from learning it. Many researchers have been made to make History become interesting to them. History is an important subject because it let us know from where we came from. Multimedia is one of the methods to make this as a reality. It gives users a fun way to explore things just at the point of the fingertip. Many parts of the humans' daily life have been replaced with interactive multimedia elements such as newspaper, watch, letters, and even the torchlight has become an app installed in the smart phone and can be fit in the pocket. Multimedia has become a part of our daily life. So, using multimedia can make History become more interesting for the students.

\section{Methodology}

The study has undertaken a few phases of processes. The first phase was preliminary study which involved interviews and literature review on subject matters. As for the interview session, 10 high-school students have been selected randomly and were asked about Islamic historical information specifically on Sultan $\mathrm{Mu}-$ hammad al-Fateh (as this research scope of study). From these interviews, seven out of the ten candidates do not know who Sul- 
tan Muhammad al-Fateh was and his contribution to Islamic revolution as well as to the whole nation. As for the other three candidates, they do hear about Sultan Muhammad al-Fateh was but they do not know about his great contribution to the nation.

This merely shows that knowledge about Islamic history is too little among Malaysian students. In addition, based on literature review, Islamic figures only cover a small part in subject 'Pendidikan Islam' in Malaysia education system. According to [15], History is a boring subject therefore, students always avoid from learning History and this is also true for Islamic history. Regarding this issue, many researchers has attempt in making History as an interesting subject to be learn [6]. Consequently, multimedia elements have been adapts and exploits to make History as an interesting subject.Based on input from the first phase, an Islamic History courseware was designed in the second phase by incorporation of mind mapping approach with adaptation of multimedia element. In designing a good mind mapping courseware, the use of colours and shapes are very important.

\subsection{Colors}

Colours do have a great affect in learning [16]. O'Brien (2016) [17] proposed that choosing right colour can affect the rate of information retrieval of information and thinking process. Learners will receive different input with a different hue coloured messages [16]. For example, negative colours can give negative effects to the learners and lead to difficulties in memorization [18] and warm colours can make learners easily recall the information being delivered. Example of colours and its effect are shown in Figure 1.

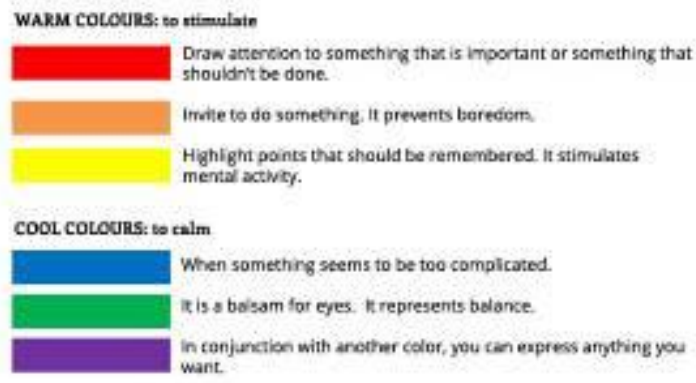

Fig. 1: List of Colors and its respective effect in learning [16]

Realizing that, students' emotion is very important in making sure the effectiveness of the courseware developed, the right combinations of colours are used. Beside colours, shapes of the mind mapping are also important.

\subsection{Shapes}

Shapes are important in mind mapping as it represents different type of information to the learners. There are five essential characteristics of Mind Mapping shapes [19]:

a. The main idea: Biggest shape that are often placed in the centre of the screen.

b. The main themes: These shapes are radiate from the central shape (the main idea) as 'branches'.

c. The branches: comprise a key shape of key word drawn or printed on its associated line

d. Topics: They are less important than the 'twig' of the relevant branch.

e. Nodal structure: the branches form a connected nodal structure.

In addition to these essential characteristics, distinctive shapes which reflected relayed information are so much essential in capturing student's attention and to increase memorization. Steps of design flow are shown in Figure 2 below.

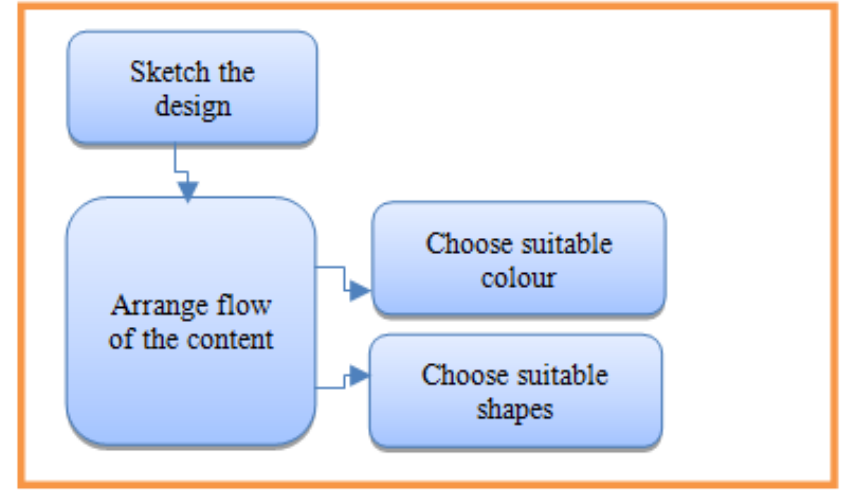

Fig. 2: Design Flow

Based on Figure 2, activities of choosing suitable colour and suitable shapes are done concurrently with arranging flow of the content's activity. All of these activities are recorded in drawn story board as shown in Figure 3.

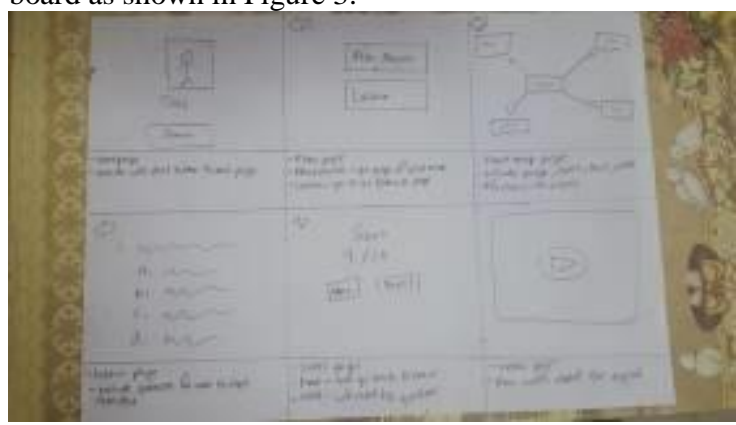

Fig. 3: Example of Storyboard during Designing Phase

After the courseware design has been finalized, the next phase of this research is development. This is where a prototype of the courseware Mind Mapping Islamic History is develops based on design in second phase. For this prototype, focus is about Sultan Muhammad al-Fateh. In the development phase, several tools are used such as Adobe Photoshop, Adobe Illustrator and Unity. An example of the development work is shown in Figure 4.

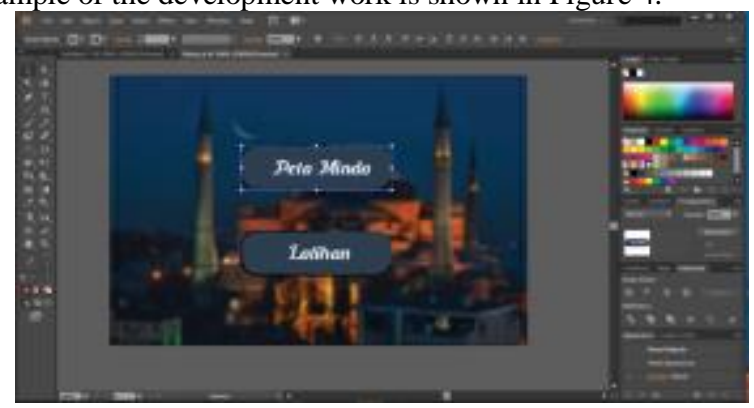

Fig. 4: Sample of work during Development Phase

All buttons and illustrations are created individually using Adobe Photoshop and Adobe Illustrator to get a fine result. A couple of screenshots of the final results are shown in Figure 5 below. 


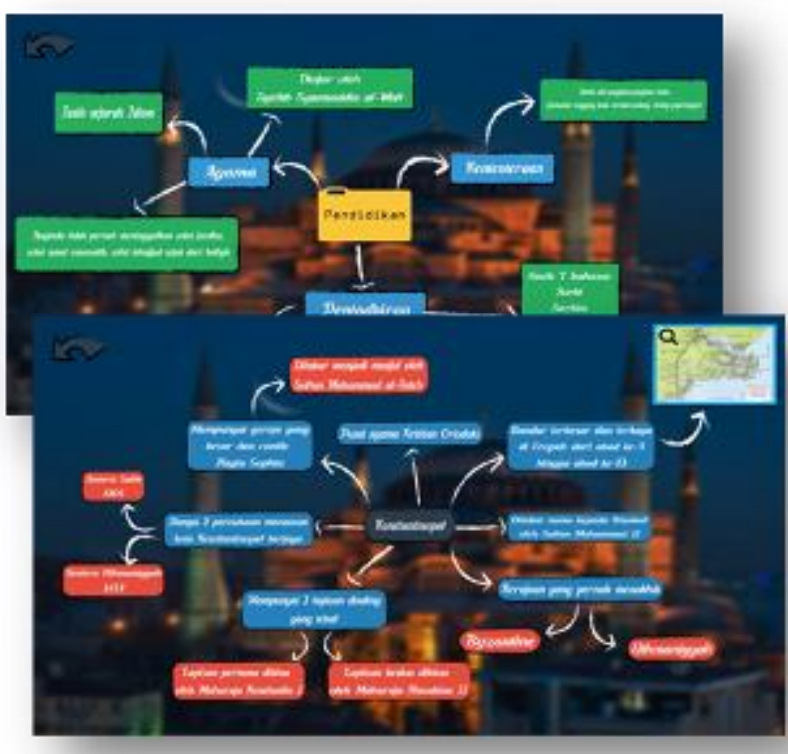

Fig. 5: Example screenshots of final product

Islamic History courseware developed is ideal for students at secondary school. Notes are captured with compact information about the subject matter. Students can navigate from one module to another. Information is also supported with other media element such as video, graphics, sound and animation. Support materials will popped out once students clicked related information. Consequently, the effectiveness of the developed courseware was tested for its effectiveness in the nest phase which is Testing Phase.

\section{Evaluation}

Objective of the testing phase is to determine whether the developed courseware has met our objective which is to effectively deliver the subject matter to the students and the students are able to memorize the subject matter for some time. For this purposes, a group of students aged $17 \mathrm{~s}$ are selected randomly as the correspondents. Each of them is undergone three consequent tests:

a. Pre-Test - A test that conducted before correspondents learn about Sultan Muhammad al-Fateh using mind mapping Islamic Historical courseware Correspondents are given books about Sultan Muhammad al-Fateh to study) (Figure 6).

b. Post-Test - A test that conducted after correspondents learn about Sultan Muhammad al-Fateh using mind mapping Islamic Historical courseware.

c. Re-Test - A test that conducted a week after correspondents learn about Sultan Muhammad al-Fateh using mind mapping Islamic Historical courseware.

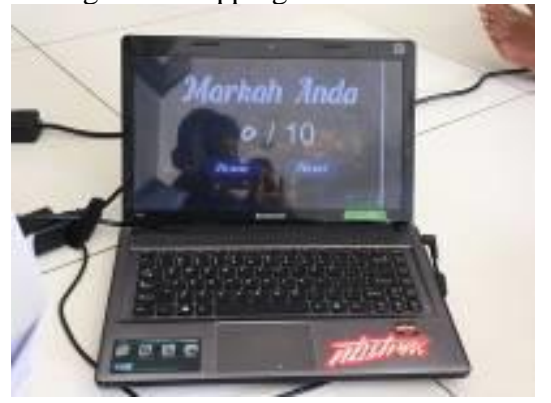

Fig. 6: Sample Result during Pre-Test Activity

For all three types of test, correspondents will be given the same set of questions. The question set consists of ten questions about Sultan Muhammad al-Fateh. As for difficulty level, questions are varying from easy, medium and difficult type. Based on the results (Figure 7), Pre-Test shows poor performance of correspondents towards their understanding on Sultan Muhammad al-Fateh while in Post-Tests, all correspondents received results above the average. And surprisingly, Re-Test shows that all correspondents are able to memorize the facts that they have learned about Sultan Muhammad al-Fateh although seven days have passed by.

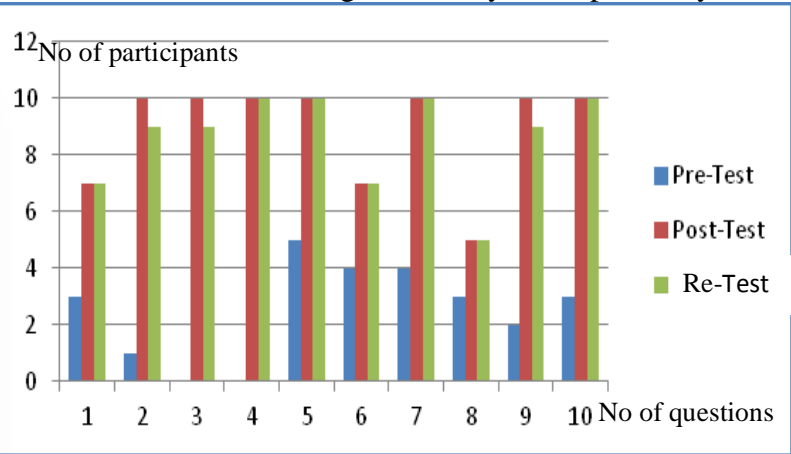

Fig. 7: Result of Pre-Test, Post-Test and Re-Test

Results of the three tests show that contestants are able to understand and memorize better using mind mapping courseware compare to just reading books. From the researchers' observation, correspondents are enjoying their time during studying via courseware compare to reading books.

\section{Conclusion}

The mind mapping method is not only can be used to arrange and organize ideas manually by the learners. Besides, it could be reversed vice versa where shared information prepared in the form of mind mapping for the learners to explore themselves. Additional effects from the multimedia elements increase learners' cognitive thinking and ability memorization capability.

This approach is suitable not only for Islamic History but also to other subjects. Therefore, teaching and learning environment can be improved from traditional approach to interactive approaches with fun and exciting ways of exploration.

\section{Acknowledgement}

The authors would like to thank Ministry of Education (MOE), MALAYSIA and Universiti Teknologi MARA for their financial support to this project under the Fundamental Research Grant Scheme (FRGS) [File No: 600-RMI/FRGS5/3 (132/2015)

\section{References}

[1] Walters, T. N., Walters, L. M., Green, M. R., \& Lin, L. H. (2016). Rich Text, Rich Teach: Expanding Educational Horizons with Technology in Malaysia. In Fast forwarding Higher Education Institutions for Global Challenges (pp. 11-24). Springer Singapore.

[2] Mai, N., Yeen-Ju, H. T., \& Ludin, N. (2016). Enhancing Malaysian Students' Learning with Interactive Multimedia and the Web: The MILE Project. In 7th International Conference on University Learning and Teaching (InCULT 2014) Proceedings (pp. 361-373). Springer Singapore.

[3] Yap, W. L., Neo, M., \& Neo, T. K. (2016). The Impact of the Role of Teacher and Balance of Power in Transforming Conventional Teaching to Learner-Centered Teaching in Malaysian Institution of Higher Education. Pertanika Journal of Social Sciences \& Humanities, 24(4).

[4] Masrom, M., Nadzari, A. S., Mahmood, N. H. N., Zakaria, W. N. W., \& Ali, N. R. M. (2016). MOBILE LEARNING IN MALAYSIA EDUCATION INSTITUTIONS. Issues in Information Systems, 17(4).

[5] Balakrishnan, V., \& Gan, C. L. (2016). Students' learning styles and their effects on the use of social media technology for learning. Telematics and Informatics, 33(3), 808-821. 
[6] Williams, S. (2016). Teaching History: Effective Teaching for Learning History-Chronological vs. Thematic Approaches to Student Historical Comprehension.

[7] Munshi, S. A., \& Zehra, F. (2015). Social Science Cyber Library, An Attempt Towards E-Learning at Aligarh Muslim University.

[8] Jones, B.D., Ruff, C., \& Snyder, J.D (2012). The Effect of Mind Mapping Activities on Students' Motivation. International Journal for the Scholarship of Teaching and Learning. $6(1), 1-21$.

[9] Novak, J. D., \&Gowin, D. B. (1984). Learning how to learn. New York: Cambridge University Press.

[10] O" Donnell, A. M., Dansereau, D. F., \& Hall, R. H. (2002). Knowledge Maps as Scaffolds for Cognitive Processing. Educational Psychology Review, 14, 71-86.

[11] Buzan, T., \&Buzan, B. (1993). The mind map book: How to use radiant thinking to maximize your brain's untapped potential. New York: Plume.

[12] The University of Adelaide (2014). Mind Mapping: Writing Centre Learning Guide.

[13] Jane (2007). How to Mind Map for Study Success. Retrieved May 22, 2016, from http://learningfundamentals.com.au/blog/how-tomind-map/

[14] Saleem, N. H., Sidhu, M. S., Adnan, N., Shafeek, N. A., \&Yousif, M. M. A. (2011). Interactive Patterns of Interactions for a Mind Mapping Multimedia Courseware. $20117^{\text {th }}$ International Conference on IT in Asia.

[15] Jasmi, K. A., Ilias, M. F., Tamuri, A. H., \& Hamzah, M. I. M. (2011). Amalan penggunaan bahan bantu mengajar dalam kalangan guru cemerlang Pendidikan Islam Sekolah Menengah di Malaysia. JIAE: Journal of Islamic and Arabic Education, 3(1), 59-74.

[16] AL-Ayash, A., Kane, R. T., Smith, D., \& Green-Armytage, P. (2016). The influence of color on student emotion, heart rate, and performance in learning environments. Color Research \& Application, 41(2), 196-205.

[17] O'Brien, S. (2016). Psychology of Colour in the Educational Environment. Retrieved May 26, 2016, from http://www.colourobjects.com/en/colour-columns/the-colourreal/item/357-ppsychology-of-colour-in-the-educationalenvironment.html

[18] Lin, F., Zhao, Z., Peng, M., \& Xie, L. (2016, October). Effect of color on pitch discrimination of pure tone. In Image and Signal Processing, BioMedical Engineering and Informatics (CISPBMEI), International Congress on (pp. 1048-1052). IEEE.

[19] Davies, M. (2011). Concept mapping, mind mapping and argument mapping: what are the differences and do they matter?. Higher education, 62(3), 279-301. 